DOI https://doi.org/10.18551/rjoas.2018-02.03

\title{
TRADING CHANNEL PATTERN OF CASSAVA COMMODITY: DOUBLE ROLES FOR THE FARMERS - IS IT A BENEFIT?
}

\author{
Kusumah Echo Perdana, Researcher \\ Department of Management, University of Bangka Belitung, Indonesia \\ E-mail: echo perdana@ubb.ac.id
}

\begin{abstract}
The results of presented study showed that farmers in addition to being producers also become a trading agency where they sell commodities directly to the nearest factory. Based on the tracing of cassava commodity trading channel pattern, two cassava channel modeling pattern in Bangka Regency of Indonesia was established: first channel, consisting of farmers, wholesaler and factories; second channel, consisting of farmers and factories. The size of the price received by farmers and the value of the cost benefit ratio differs in each trading channel pattern.
\end{abstract}

\section{KEY WORDS}

Cassava, trading channel, market behavior, market structure, trade margin.

The development of cassava productivity in Indonesia during 1980-2016 tended to increase, along with the increase of farmers' passion to grow superior cassava varieties of Gajah. The growth rate of cassava productivity in Indonesia increased by an average of $2.64 \%$ per year, productivity of $97.51 \mathrm{ku} /$ ha in 1980 to $239.13 \mathrm{ku} /$ ha in 2016 . The last five years productivity (2011-2016) increased by $2.85 \%$, despite a decline in cassava production by 2015 compared to 2014 (Nuryati, Waryanto \& Akbar, 2016). The second largest contributor of agriculture, forestry and fishery with an added value of Rp 13.02 trillion (BPS Babel, 2016).

In terms of demand, there are several factors that need to be considered: (1) The cheaper the number of people interested in cassava varieties of Gajah as a result of government persuasion accompanied by the emergence of cassava processing factory or also called Tapioca Plant in Riausilip, Kenanga and Indonesia's largest factories in Puding Besar Sub-district (Bangka Pos, 2016), (2) Cassava Price Level at Factory, and (3) Other tuber price level. In terms of supply, several factors develop cassava, hai: (1) Cheap trends of cassava plant area, (2) climate, (3) price of production means, and (4) cassava technology development.

The development of cassava in Bangka Regency is divided into increasing harvested area and the presence of cassava / tapioca processing factories that are ready to accommodate cassava products in small and large scale. Cassava crop is one of agriculture product that has easy and low maintenance. In other words, the cassava, the productivity of the cassava commodity is necessary. What is needed by factory or consumer directly in good condition and quality.

Bangka Belitung Islands is one of the areas of cassava production centers outside Java Island and Bangka Regency is one of the largest cassava producing areas with the largest harvest area of 520 ha in Bangka Belitung Islands. However, the area of harvest area is not in accordance with the production output in 2015 as much as 1314 tons compared to West Bangka Regency which has 12,910 tons of production with harvest area of 505 ha (KBBDA, 2016). The condition of cassava production in Bangka Regency is contradictory or inversely proportional to the result of national cassava analysis, where the decrease of national cassava production in 2015 is due to the decrease of harvested area. So that the commodity of cassava food in Bangka Regency need to get an intensive handling in handling post-harvest constraints and marketing, especially in terms of trading.

Based on the problems that have been described above, the formulation of problems in this study are: 
1. How many trading agencies or market participants are involved, how is the pattern of trading channels formed and what is the function of each of the trading agencies on the market of cassava commodity in Bangka Regency?

2. What is the market structure in every trading agency faced by the cassava commodity in Bangka Regency and how is the market behavior in each of the trading agencies involved?

3. What is the marketability of the cassava trading system in Bangka Regency based on the trading margin, the farmer's share, the profit and cost ratio?

\section{METHODS OF RESEARCH}

The research was conducted at the location determined by the researcher with the consideration that the selected location is the producer of cassava. The locations selected for the sampling are several sub districts in Bangka Regency, Indonesia. In analysis of trading commodity of cassava, the data used are primary data and secondary data. The determination of farmers and non-farmers respondents was based on information obtained from the analysis team of researchers in each district sample, and in each sub-district only 10 farmers and non-farmers were selected. The sampling of marketer institutions is then carried out by using the snowball sampling method, by tracing the dominant cassava marketing channel in the research area based on information obtained from the analysis team and the marketing actors.

The channel analysis of a marketing agency is used to identify market participants involved in the distribution of cassava commodities from farmers to final consumers. To find out the market structure of cassava commodity that can be seen based on the number of marketing institutions involved, easy access to enter the market, product differentiation, and market information. Then, market behavior can be analyzed by observing sales and purchasing practices conducted by market participants through a system of price determination and dissemination, and cooperation among involved marketing agencies. While the analysis of farmer's share price and the value of ratios and profits can be analyzed with a trading margin which is the price difference received by the manufacturer at a price paid by the consumer.

\section{RESULTS AND DISCUSSION}

In trading there are activities related to the delivery of products from farmers (producers) to consumers, as well as activities resulting in changes in the shape of the product, which is intended to facilitate the distribution and provide satisfaction to consumers by seeking for consumers to obtain the desired goods on the spot, time, form and price.

Table 1 - Distribution of Cassava Average Price and Margin of Trade on the Pattern of Cassava Code Line

\begin{tabular}{|c|c|c|c|c|}
\hline \multirow{2}{*}{\multicolumn{2}{|c|}{ Trading Function }} & \multicolumn{3}{|c|}{ Trading Institution } \\
\hline & & Farmers & Traders & Factory \\
\hline \multicolumn{5}{|c|}{ Exchange } \\
\hline$\bullet$ & Buying & - & + & + \\
\hline$\bullet$ & Selling & + & - & + \\
\hline \multicolumn{5}{|c|}{ Physical } \\
\hline$\bullet$ & Packaging & - & - & + \\
\hline$\bullet$ & Storage & - & $\#$ & + \\
\hline$\bullet$ & Transporting & $\#$ & + & + \\
\hline$\bullet$ & Processing & - & - & + \\
\hline \multicolumn{5}{|c|}{ Facility } \\
\hline$\bullet$ & Sorting & - & + & + \\
\hline$\bullet$ & Grading & - & - & + \\
\hline$\bullet$ & Financing & - & \# & + \\
\hline$\bullet$ & Risk taker & - & + & + \\
\hline$\bullet$ & Market information & + & + & + \\
\hline
\end{tabular}

Notes: - Activity not done, \# Activity sometime done, + Activity done. 
These activities are called the marketing functions. Each of the trading agencies involved in the distribution of cassava from farmers to final consumers, performs various trading functions that are generally grouped into three main functions, namely: exchange function, physical function, and facility function.

Table 1 illustrates the overall functions of the trade-offs undertaken by the trading agencies involved in the delivery of cassava commodities from farmers to consumers, and in general, every agency institution performs different functions. The functions of the business when implemented well and efficiently can reduce the cost of the business. The exchange function explains the occurrence of transfer of ownership of the goods from the seller to the buyer in the process of sale and purchase through the transaction. Based on the search of cassava commodity lines, starting from the point of producer farmer to the factory which is directly related to the end consumers, there are two patterns of cassava farming channels in Bangka Regency, namely:

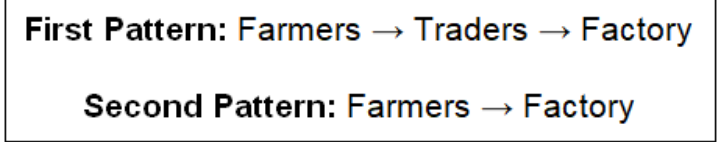

The pattern of cassava channel in Bangka Regency does not vary, this is not separated from the limited production of cassava. The selection of marketing channels is based on several things, namely: selling price, transportation distance, source of purchase, and sales objectives. Although there are several different patterns of trading channels, it is still a unity of a cassava commodity trading system that physically consists of interrelated parts and cooperates in an organized and integrated system.

The market structure faced by cassava growers in Bangka Regency tends to lead to a perfectly competitive market structure, as seen from the number of farmers far more than the number of traders. The nature of products owned by a farmer is generally uniform or homogeneous. In price determination, farmers tend to be price takers and do not have a strong bargaining position even though farmers have price information obtained from peers and traders. Farmers can't affect the market price. The market structure faced by cassava collecting traders in Bangka Regency tends to lead to a perfectly competitive market structure, as seen from the number of farmers far more than the number of traders. Although, collecting traders are generally located in every village in the cassava production centers and more than one in each village. At the factory, the market structure formed tends to oligopoly market structure. This is seen from the number of factories that are not too much when compared with the number of wholesaler. The nature of the products received by the factory, both from farmers and from wholesaler have a very diverse quality. Sales conducted by the factory also describes the condition of products that vary based on the quality of the product based on the size and physical condition.

In the market behavior, farmers sell cassava to local collectors and mills in the form of bulk without sorting and grading. Sales of collecting traders to factories are also in the form of wholesale, collecting traders are seldom or rarely found make a grading before making a sale to the factory. The main reason why farmers and collecting traders are reluctant to sort is due to the sorting and grading when making a sale. Sorting and grading have become standard when collecting traders sell the cassava to factories. In general, buying and selling systems that are free and subscribed. Farmers are free to sell cassava to their destination traders, if the price agreement in the sense of farmers is less profitable, the farmer can sell his product to the other traders. Collecting traders to sell to the factory is also a free sale and purchase, without any contractual ties in the system of sale and purchase is done. If the price agreement that occurs in the taste by the collecting traders is less favorable, usually the wholesaler sells to another factory. Unlike the case with what happened in Bangka Regency, wholesaler have little choice to determine which factory to visit if the price position is not suitable, it happens because of the limited number of factories in the Bangka Belitung 
Islands. Not only the limited number of existing factories, but the purchase price offered by the factory tends to be the same.

The trading margin in the case of cassava in Bangka Regency is the difference in price or price difference paid by the factory at the price received by farmers. The trading margin analysis is used to determine the largest form of margin of trading as a measure of efficiency of trading of cassava commodity in Bangka Regency. The margin distribution in each channel pattern is quite different (see Table 2).

Table 2 - Distribution of Cassava Average Price and Margin of Trade on the Pattern of Cassava Code Line

\begin{tabular}{|c|c|c|c|c|c|}
\hline \multirow{2}{*}{$\mathrm{n} / \mathrm{n}$} & \multirow{2}{*}{ Margin Element } & \multicolumn{2}{|c|}{ First Channel Pattern } & \multicolumn{2}{|c|}{ Second Channel Pattern } \\
\hline & & Price $(\mathrm{Rp} / \mathrm{Kg})^{*}$ & Percentage (\%) & Price $(\mathrm{Rp} / \mathrm{Kg})^{*}$ & Percentage (\%) \\
\hline \multirow[t]{5}{*}{$\mathrm{A}$} & Farmers & & & & \\
\hline & Selling price & 525 & 72,41 & 725 & 100 \\
\hline & Trading cost & & & 125 & \\
\hline & Profit & & & 600 & \\
\hline & Margin & & & 725 & \\
\hline \multirow[t]{6}{*}{$\mathrm{B}$} & Traders & & & & \\
\hline & Buying price & 500 & & & \\
\hline & Trading cost & 125 & & & \\
\hline & Profit & 100 & & & \\
\hline & Selling price & 725 & 100 & & \\
\hline & Margin & 225 & & & \\
\hline \multirow[t]{5}{*}{$\mathrm{C}$} & Factory & & & & \\
\hline & Buying price & 725 & & 725 & 100 \\
\hline & Total Trading cost & 125 & & 125 & \\
\hline & Total Profit & 100 & & 600 & \\
\hline & Total Trading margin & 225 & & 725 & \\
\hline
\end{tabular}

Notes: * Rp (rupiah) as Indonesian currency, * Kg (kilogram).

In the pattern of channel 1 consisting of farmers, collecting traders, and factories, the total margin of Rp. 225 per kilogram for a total cost of Rp. 100 per kilogram. Components of costs borne by the collecting traders are labor costs of Rp. 50 per kilogram, goods transportation cost of Rp. 50 per kilogram, and the cost of accommodation which includes the cost of labor consumption, and the cost of weighing Rp. 25 per kilogram. In the pattern of channel 2 consisting only of farmers and factories, the total margin of Rp. 725 per kilogram for a total cost of Rp. 125 per kilogram. Based on the tables of distribution margin above, it can be seen that the distribution of margin in every pattern of trading channel of cassava commodity in Bangka Regency is different.

The share of the price received by the farmer or farmer's share is the ratio of the price received by the farmer to the price paid by the wholesaler or factory at a higher level of trading agency, and is generally expressed as a percentage. Part of the price received by farmers is the concept of a reward for the activities of farmers in cassava farming. The amount of farmer's share can be seen in each channel pattern of trading. In the trading of cassava commodity, the amount of price received by farmers is different on each channel pattern. In the pattern of channel 1, the share of prices received by farmers is 72.41 percent and in channel pattern 2, the share of prices received by farmers is 100 percent. Based on the description of the share of farmer's share price in each channel pattern above, it can be seen that the share of the price received by the largest farmers is in channel pattern 2 , this is related to the shortness of the trading channel. Part of the price received by the smallest farmer is on channel 1 , this is because there is a trading channel in the form of collecting traders so that the reduction of farmers profit. The large part of the price received by farmers does not always show the high selling price of cassava at the farm level. Differences in the farmer's share of the price on each trade channel pattern are influenced by the formation of the selling price at the highest level of the trading agency.

Cost-benefit ratios are used to determine the spread of benefits and costs at each of the trading agencies involved in each of the trading channels. This ratio shows the amount of 
profits that a trading agency receives on the trading costs incurred by the trading agency on a channel pattern of trading (see Table 3 ). Higher ratio value can show greater gain.

Table 3 - Cassava Trading Pattern

\begin{tabular}{|c|c|c|c|}
\hline Trading Institution & Profit (Rp/Kg) & Cost (Rp/Kg) & Cost-Profit Ratio \\
\hline Trading Pattern 1 & & & 0,80 \\
\hline Traders & 100 & 125 & 4,80 \\
\hline Trading Pattern 2 & & & 125 \\
\hline Farmers & 600 & & \\
\hline
\end{tabular}

Based on Table 3, it can be seen that the value of the cost-profit ratio of each agency in the trading channel shows the value of different cost-profit ratios. The greatest cost-profit ratio value is at the farm level in channel pattern 2 , which is 4.80 . Profit ratio value of 4.80 means, that of every Rp. 1 per kilogram of trading costs incurred by the farmer will generate a profit of Rp. 4.80 per kilogram. The smallest cost-to-gain ratio value is at the collecting trader level in channel pattern 1 of 0.80 . Profit ratio value of 0.80 means, from every Rp. 1 per kilogram of trading costs incurred by the collector will generate a profit of Rp. 0.80 per kilogram.

\section{CONCLUSION}

In the cassava business activity, it involves two agencies in the delivery of cassava commodities from farmers to industries (local factories), namely: collecting traders and farmers. Farmers have a dual role in which farmers are apart from being producers, farmers are also a farming institution where the farmers directly sell their commodities to the nearest factory. Every business institution generally performs different marketing functions based on its marketing interests and objectives. The functions of the business undertaken by the regulatory agencies are grouped into three main functions, namely: exchange function, physical function, and facility function.

Based on the search for cassava commodity line pattern, there are two pattern of cassava farming channel in Bangka Regency, namely: channel 1 pattern consisting of farmers, collecting and factory traders; channel 2, consisting of farmers and factories. The market structure that is formed at every level of the trade institution in the cassava commodity business can be different. The market structure faced by cassava farmers tends to lead to the perfect competition market structure. In collecting traders, the market structure that is faced tends to lead to the perfect competition market. At the factory, the market structure that formed is likely to be the oligopoly market structure.

Market behavior can be seen from the practice of sales and purchases conducted by each agency, pricing system, payment system, and cooperation among various business institutions. Sales and purchase practices are a form of good co-operation between business institutions as a way to create market stability. The pricing system is through a bargaining system and unilateral pricing system, and on determining the selling price of the farmer's position only as Price Taker. The price formed is the price set up by the market mechanism. Cash payment system is made in the form of cash payment system, advance payment system and later payment system. The ongoing payment system depends on the level of trust and agreement between the two parties. Cooperation formed between farmers and business institutions generally lasts long, resulting in good relationships and mutual trust.

The cassava commodities market analysis is analyzed using the margin analysis of the farmer's share price and the cost-profit ratio. The margin distribution of each business institution in each channel pattern is quite different. The difference in marginal distribution in each channel pattern is influenced by several factors, including: the number of business agencies involved in each channel pattern; the amount of the cost of the business being issued and the magnitude of the profits earned by each business institution on a channel pattern. The size of the price of different farmer's receipts on each channel pattern, the difference in the price of the farmer's share of each trader's channel pattern is influenced by 
several factors, including: the small size of the trading margin formed in every pattern of the channel of the business, low and high price at the consumer level or selling price at the highest level of institutional level. The value of the profit gains ratio at each of the business institutions in the line of trade shows the different cost advantages ratio.

\section{REFERENCES}

1. BPS (Central Bureau of Statistics). (2016). Value of Gross Domestic Product (GDP) by Industrial Origin at Constant Price (Billions of Rupiah). (Rep.). Retrieved from https://www.bps.go.id/linkTable Dynamic / view / id / 827

2. Brogaard, J., Hendershott, T. and Riordan, R. (2014). High-frequency trading and price discovery. The Review of Financial Studies, 27(8), pp.2267-2306.

3. France, S.L. and Ghose, S. (2016). An analysis and visualization methodology for identifying and testing market structure. Marketing Science, 35(1), pp.182-197.

4. Hildenbrand, W. (2014). Market demand: Theory and empirical evidence. Princeton University Press.

5. KBBDA (Central Bureau of Statistics Bangka Belitung). (2016). Province of Bangka Belitung Island in Numbers. Retrieved from http://babel.bps.go.id/ backend/pdf_publikasi/Provinsi-Kepulauan-Bangka-Belitung-Dalam-Angka-2016.pdf

6. Kotler, K. (2014). Marketing Management., 0(1), 111. https://doi.org/10.1890/092296.1.Abrams

7. MacMillan, T. and Benton, T.G. (2014). Engage farmers in research. Nature, 509(7498), p.25.

8. Nuryati, L., Waryanto, B., \& Akbar, A. (Eds.). (2016). Cassava Outlook. Retrieved from http://epublikasi.setjen.pertanian.go.id/arsip-outlook/81-outlook-tanaman-pangan/429outlook-ubi kayu-2016

9. Purwono. (2009). Cultivation 8 Types of Superior Crops. Jakarta: Spreading Self-Helpers.

10. Sabarella. (Eds). (2014). Food Consumption Bulletin 2014. Retrieved from http://epublikasi.setjen.

pertanian.go.id/epublikasi/buletin/konsumsi/2014/konsumsi_tw1_2014/index.html\#/1/

11. Sasongko, L. A. (2009). Development of Sweet Potato and its development opportunities to Support the Food Consumption Diversification Acceleration Program in Central Java. Mediagro, 5 (1), 36-43.

12. Sodenkamp, M.A., Tavana, M. and Di Caprio, D. (2016). Modeling synergies in multicriteria supplier selection and order allocation: An application to commodity trading. European Journal of Operational Research, 254(3), pp.859-874.

13. Ukeje, B.A., Ogbonna, M.C., Okonkwo, I.I. and Adiele-Ezekiel, C. (2017). Deteminants of market orientation among cassava producers in Abia state, Nigeria. Nigeria Agricultural Journal, 48(1), pp.214-223. 